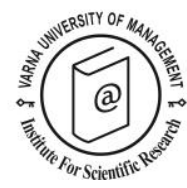

\title{
Antecedents and outcomes of a City's Global Image: the impact of a tourist staple
}

\author{
Cristela Bairrada ${ }^{1}$, Maria Vieira ${ }^{2}$ and João Fontes da Costa ${ }^{3 *}$
}

Received: 19/03/2018 Accepted: 06/09/2018

\begin{abstract}
1 CeBER; Faculty of Economics, University of Coimbra, Portugal. E-mail: cristela.bairrada@uc.pt, Av. Dias da Silva, 165, 3004-512 Coimbra, Portugal, +351 790575

2 Higher Institute for Accountancy and Administration of Aveiro University, Portugal; E-mail: mariaeirinha@gmail.com, Rua Associação Humanitária dos Bombeiros Voluntários de Aveiro, 3810-902 Aveiro, Portugal, +351234380110

3 CeBER, Faculty of Economics, University of Coimbra, Portugal. E-mail: fontesdacosta@fe.uc.pt, Av. Dias da Silva, 165, 3004-512 Coimbra, Portugal, +351 239790 575)

* Corresponding author
\end{abstract}

\begin{abstract}
It is paramount to understand the impact of distinctive features in a city's global image. This research was based on a questionnaire to tourists who visited Coimbra, Portugal $(n=255)$, a city best known for its 727-year-old University. Results showed that the affective image and the personality of the University of Coimbra brand has a direct influence on the city's global image as a tourist destination. Results also showed that the global destination image has a positive impact on satisfaction. Overall, there are impacts of memorable experience in affective image and of satisfaction in brand evangelism. A distinctive feature is forcedly an anchor for the city's brand development; separate and unrelated brand strategies for a tourist staple and the city can be conflicting.
\end{abstract}

(C) 2019 Varna University of Management. All rights reserved

Keywords: Destination Image; brand personality; brand evangelism; satisfaction.

Citation: Bairrada, C., M. Vieira and J. Fontes da Costa (2019) Antecedents and outcomes of a City's Global Image: the impact of a tourist staple. European Journal of Tourism Research 21, pp. 87-101

\section{Introduction}

In the past few decades, considering the exponential increase in tourism, it has become increasingly important for tourist destinations to develop effective strategies to remain competitive. This necessity exists due to the market in which destinations have become increasingly replaceable with one another, through the offer of similar characteristics and communication strategies that are targeted to the same market segments (Agapito, Mendes, \& Valle, 2010; Chi \& Qu, 2008; Hudson \& Ritchie, 2009).

A tourist destination consists of several independent interest groups that, in turn, have 
concrete and different goals and plans; and also of its residents, who act simultaneously as recipients and producers of the destination's brand image (Freire, 2011). However, due to the intangibility of tourist destinations, factors such as brand image, communication, and destination branding, have generally become essential to promote and develop the destination. A tourist's special interest for a destination will contribute to the decisionmaking process and influence his/her future behaviours. In addition, it is important to bear in mind that building a brand image adds competitive advantages to a destination as its attributes are promoted with the objective of increasing demand.

Thus, this research will focus on a detailed analysis of the global destination image, as it corresponds to the "perceptions of individual product attributes, as well as total, holistic, impressions' (Echtner \& Ritchie, 2003, p. 40). The originality of this paper relies on the way the Brand Personality of a University can contribute to the formation of a City's (Destination's) Global Image. The object is the city of Coimbra, located in central Portugal. According to Santos (2012), Coimbra is one of the eight Portuguese cities with more than one hundred thousand inhabitants, making it one of the largest urban centres in Portugal. Considered a medium-sized city (compared to cities such as Lisbon and Oporto) (Araújo, 2015), and with the University occupying a central place in the urban environment, the city has seen a significant evolution of tourism in the last decades, mainly in the historical centre (Araújo, 2015). In addition, it has the advantage of having a good network of transport accessibility, which allows it to be permanently linked to the main Iberian and European urban centres (Domingues \& Carvalho, 2013).

It is also worth noting that the University of Coimbra (UC), Alta (Uptown) and Sofia (a downtown street) have recently been included in the World Heritage List of the United Nations Educational, Scientific and Cultural Organization (UNESCO), indicating a unique cultural heritage. This recognition offers new opportunities for tourism operators in the city, since the official distinction of its historical and cultural attractions act as a global "recom- mendation" to visit and appreciate these places, raising its credibility and creating a "brand" (Poria, Reichel, \& Cohen, 2013). On the other hand, tourism is considered one of the most relevant activities for uptown Coimbra (the historical area comprising the parishes of Almedina and Sé Nova) and this is where the greatest number of classified tourist attractions, such as the University of Coimbra, are located (Araújo, 2015). With a history dating back to the onset of the Portuguese nation (the papal recognition of Portugal dates from 1179 and the pontificate confirmation of the University dates from 1290), the University of Coimbra constitutes an indispensable reference for Portuguese culture and is a synonym of innovation, both past and present.

The main objective of the current study is to understand the process behind the construction of a destination's global image and the inherent attitudinal consequences. Based on this central concept, this research aims at understanding the antecedents (memorable experiences, affective and cognitive images and the personality of the brand UC) and outcomes (satisfaction and brand evangelism) of the global image of the brand 'city of Coimbra', Portugal. This study is also important because it acknowledges that, in the future, not only Coimbra, but also other cities could be able to develop marketing strategies that support their ability to reach different target audiences, supported on the evidence that a tourist staple is important for a destinations' global image.

\section{Literature Review and Research Hypotheses \\ Global Image of the Destination}

According to Chan \& Marafa (2016, p. 1285) 'understanding the image and the perception of a city is a prerequisite when establishing a successful place brand'. It can be said that the increase in the interest related to these concepts is due to the fact that the offering of tourist destinations has increased exponentially, making them gradually replaceable (Pike \& Ryan, 2004). Thus, more and more destinations are eliminated from the selection process due to their similar attributes and only those with a strong destination image will move on to the next decision phase (Gartner, 1994; 
Hosany, Ekinci, \& Uysal, 2006; Tasci \& Gartner, 2007).

Therefore, it is important for a tourist destination to define its brand and its global image (Brea \& Cardoso, 2011; Kim, Holland, \& Han, 2013; Kim \& Perdue, 2011; Matos, Mendes, \& Valle, 2012; Qu, Hyunjung, \& Hyunjung, 2011). The concepts of destination brand (Li \& Kaplanidou, 2013) and destination image (Hernández-Mogollón, Duarte, \& Folgado-Fernández, 2016) are often confused (Tasci \& Kozak, 2006); although literature does not converge, our standing, following the work of Hernández-Mogollon et al., (2018, p. 171), is that "image is only one part of the more global concept of brand, which results from the associations created with brands". The image that tourists have of a destination derives from the overall experiences and perceptions (Bigné, Sanchez, \& Sanchez, 2001; San Martín \& Rodríguez del Bosque, 2008; HernándezMogollon et al., 2018).

Moreover, a favourable brand image can have an impact on the choice of the destination, the positive experience in the destination, levels of satisfaction, and, consequently, a higher loyalty; which translates into the intention to revisit and recommend the destination to others (Lee, Lee, \& Lee, 2014).

Antecedents of Global Image of the Destination The subsequent sections will provide detail about four potential antecedents of the global image of the destination which are as follows: i) the memorable experience, ii) the affective image, iii) the cognitive image, and iv) the brand personality of the University of Coimbra. These antecedents were selected based on the cognitive-affective dichotomy of the destination image, as proposed by several works and authors (Baloglu \& Brinberg, 1997; Baloglu \& McCleary, 1999; Echtner \& Ritchie, 1993; Hernández-Mogollón et al., 2018; Pike \& Ryan, 2004; Chi \& Qu, 2008; Stern \& Krakover, 1993). Cognitive and affective aspects interact in shaping a unique overall image, including positive and negative evaluations, forming a global impression of the place (Baloglu \& McCleary, 1999; Hernández-Mogollón et al., 2018).

\section{- Memorable Experience}

Some reports claim that today's tourists are looking for an authentic and unique tourist experience, devoid of the mass activities that many destinations still promote with the aim of attracting all market segments, instead of just one in particular (Buhalis, 2000). Tung \& Ritchie (2011) defined the experiences in tourism as an individual's subjective evaluation (i.e. affective, cognitive, and behavioural) and an undergoing of events related to tourist activities, which begin before (i.e. planning and preparation), and continue during (i.e. at the destination) and after the trip (i.e. recollection) (Tung \& Ritchie, 2011).

Bearing this in mind, it is only natural that several tourist destinations are now investing on the development of a clear and unique positioning, through the creation of branding strategies that focus more on the intangible experience rather than solely on the physical attributes of the destination (Hudson \& Ritchie, 2009). The memorable experience of a destination corresponds to the subject, and there is continuous evaluation by a tourist of its touristic activities before and during the visit to the destination. This variable has become one of the central points of the studies related to tourism and tourism management (Tung \& Ritchie, 2011). According to Prayag et al. (2017), the results of a study conducted on domestic tourists visiting Sardinia in Italy showed that the emotional experiences of tourists are unique and memorable, acting as antecedents of perceived image, suggesting the better the tourists' experience, the better image of the destination is formed (Pais, 2015). Considering this line of thought, the following hypothesis was established for this investigation:

H1: The memorable experience has a positive impact on the affective image of the destination.

\section{- Affective Image}

This component corresponds to the evaluation process of the reasons for selecting a particular tourist destination, i.e., the feelings the destination awakens in the tourist, and the affective evaluation of that place, which can be positive, neutral or negative (Agapito, Valle, \& 
Mendes, 2013; Andrades-Caldito, SanchezRivero, \& Pulido-Fernandez, 2012; Baloglu \& Brinberg, 1997; Baloglu \& Mccleary, 1999; Gartner, 1994; Hosany et al., 2006; Lee, 2009; Martín \& Bosque, 2008; Matos et al., 2012; Pike \& Ryan, 2004). It focuses on the individual feelings of the tourist towards the destination and on the experiences, which are influenced by his/her personal motivations and cognitive perceptions (Baloglu \& Mccleary, 1999; Beerli \& Martín, 2004; Kim \& Perdue, 2011).

As stated by several authors (Agapito, Valle, \& Mendes, 2013; Baloglu \& Brinberg, 1997; Bosque \& Martín, 2008; Pike \& Ryan, 2004 and Zhang, Fu, Cai, \& Lu, 2014), the affective image can be defined as an emotional response taking into account the experiences in a particular destination. According to Brea \& Cardoso (2011), the global image of a destination is based on the attributes (resources available at the destination), both individually and in an holistic form, constructing a mental imaginary of the destination as a whole. Therefore, it can be stated that the affective image influences the global image of the destination. Considering these facts, it is possible to postulate the following hypothesis:

H2: The affective image has a positive impact on the global destination image.

\section{- Cognitive Image}

This component refers to the beliefs and the knowledge of the objective attributes of a place, which can be either organic or induced (Agapito et al., 2013; Andrades-Caldito et al., 2012; Baloglu \& Mccleary, 1999; Brea \& Cardoso, 2011; Hosany et al., 2006; Kim \& Perdue, 2011; Lee, 2009; Martín \& Bosque, 2008; Matos et al., 2012; Pike \& Ryan, 2004). This knowledge can be related to tangible/functional aspects (e.g. landscape, cultural attractions) or with psychological/abstract aspects (e.g. hospitality, atmosphere) (Martín \& Bosque, 2008). Theoretically, it is considered as an antecedent of the destination image, having an important role in the tourists' evaluation; therefore, creating and projecting images of the destination is an important part of the promotion and branding of the place
(Andrades-Caldito et al., 2012; Matos et al., 2012).

According to Chen \& Tsai (2007) and Martín \& Bosque (2008), the global destination image can be influenced by more than one component, being that the cognitive image is the most extensively studied among them. Taking into account the facts that the cognitive image can be defined as the beliefs and knowledge that an individual has of the characteristics and attributes of a certain tourist destination (Martín \& Bosque, 2008), and that the global destination image corresponds to the result of the perceptual/cognitive and affective evaluation about a certain destination (Brea \& Cardoso, 2011), it makes sense that the cognitive image influences the global destination image. This idea was previously proposed by Stern \& Krakover, (1993), who have empirically shown that the cognitive interpretation has a direct influence on the formation of the global image of the destination. Thus, it is possible to propose the following hypothesis:

H3: The cognitive image has a positive impact on the global destination image.

\section{- Personality of the University of Coimbra brand}

Brand personality corresponds to the set of human characteristics associated with a brand' (Aaker, 1997, p. 347), influencing the consumer's preference, behaviour, and experience (Pan, Zhang, Gursoy, \& Lu, 2017; Rauschnabel, Krey, Babin, \& Ivens, 2016; Rutter, Lettice, \& Nadeau, 2016). Aaker defined the 'Brand Personality Scale' (BPS), which consists of a study involving the 'big five' human personality traits for the analysis of the brand personality concept ( Aaker, 1997; Pan et al., 2017; Rutter et al., 2016). These five characteristics are sincerity, excitement, competence, sophistication, and ruggedness (Aaker, 1997; Pan et al., 2017; Rutter et al., 2016).

According to Pan et al. (2017), tourism academics have adapted the concept of brand personality from marketing to tourism, creating the concept of 'personality of the destination'. This concept can thus be defined as the set of 
human characteristics associated to a tourist destination' (Hosany et al., 2006, p. 639). Furthermore, and considering the theme of this paper/chapter, it becomes pertinent to address the study of the brand personality of universities. Universities' personality can be defined as the traits of those that consider them as being friendly, stable, practical and welcoming (Sung \& Yang, 2008).

Brand personality corresponds to a process of anthropomorphising the brand with influence on its image. Keeping this in mind and as showed by Hosany et al (Hosany et al., 2006), it can be inferred that a destinations' personality has a positive impact on the perceived image of the destination influencing the consumers' future behaviour as well. Therefore, on the one hand, the brand personality of a university is defined as its ability to be friendly, stable, practical, and welcoming, representing the feelings associated with it (Rauschnabel et al., 2016; Sung \& Yang, 2008), whereas the global destination image of Coimbra is based partially on its university, as reported in the introduction. Thus, it can be assumed that the former influences the latter. This investigation aims to demonstrate specifically how the personality of the brand UC (University of Coimbra) relates to the global image of the 'city of Coimbra' as a destination. Therefore, a hypothesis was postulated as follows:

H4: The personality of the brand UC has a positive impact on the global destination image.

\section{Outcomes of Global Destination Image}

After analysing the potential antecedents of the global destination image, two potential outcomes can be derived from this central variable: satisfaction and brand evangelism (subdivided into intention to revisit, intention to recommend, and opposition to competing destinations).

\section{- Satisfaction}

According to Şahin, Zehir, \& Kitapçi (2011) satisfaction can be defined as an effective response to a situation of purchase, which in this case is positive. Managing and measuring the level of tourists' satisfaction is essential to the success and development of tourist destinations (Prayag et al., 2017). However, it is important to note that satisfaction must be evaluated through more than one way. If a consumer has low expectations, he/she will feel some degree of satisfaction, but that alone does not imply the quality of the destination.

On the one hand, satisfaction corresponds to the 'positive reaction resulting from favourable appraisals of consumption experiences (Prayag et al., 2017, p. 44). On the other hand, the global destination image can be defined in part as the overall impressions that a tourist gets from a destination (Baloglu \& Mccleary, 1999). According to Bigné, Sánchez, \& Sánchez (2001), the satisfaction of tourists is positively influenced by the image of the destination (Bigné et al., 2001; Chen \& Phou, 2013; Kim et al., 2013; Lee, 2009; Pais, 2015). It is, thus, possible to postulate the following research hypothesis:

\section{H5: The global destination image has a positive impact on satisfaction.}

\section{- Brand Evangelism}

The term brand evangelism means 'an intense form of brand support behaviour' (Becerra \& Badrinarayanan, 2013, p. 371). Becerra \& Badrinarayanan (2013) reported that the way in which consumers relate to a brand can influence their brand evangelism. It is based on a consumers' strong identification with a product or service, creating bonds and making him/her feel the need of promoting it to others (Patel, 2015). As can be concluded from the definition of Becerra \& Badrinarayanan (2013), brand evangelism is linked with three other variables: intention to purchase (to revisit), positive referrals to the brand (intention to recommend), and opposition to competing brands (opposition to competing destinations).

\section{Intention to Return (Revisit)}

There are several authors who claim that today's tourists are constantly looking for more authentic and unique tourist experiences, disregarding the mass activities that many destinations still promote, with the purpose of attracting every market segment (Buhalis, 2000). A tourist is more likely to return to a destination with a favourable global image (Agapito, 2010; Chi \& Qu, 2008; Lee, 2009). 
Oppermann (2000) presented five reasons for people to revisit a certain destination that can be summarised as: i) risk reduction/content with destination, ii) risk reduction through the search of the same type of people, iii) to develop emotional bonds to a place, iv) to deeply explore the destination, and to v) show the destination to other people.

According to several studies the global image of a destination influences the attitudes and future behaviours of the tourist (Assaker, Vinzi, \& O'Connor, 2011; Bigné et al., 2001). One of the behaviours that can be taken into account is the intention to return (revisit), which is defined as the future behaviour of a tourist related with the positive evaluations made in a previous visit to a certain destination (Bigné et al., 2001; Mat Som, Marzuki, Yousefi, \& AbuKhalifeh, 2012). Kock, Josiassen, \& Assaf (2016) reported that researchers often study the intention of returning to a destination. They also mentioned that the global image of a destination has a positive influence in this variable. Taking this into account, the following hypothesis was proposed:

\section{H6: Satisfaction has a positive impact on the intention to return.}

\section{Intention to Recommend (Word of Mouth)}

The intention to recommend is intrinsically connected to the tourists' satisfaction and can be defined as: the positive tourists' perceptions considering a destination through his/her leisure experiences, influencing the choice of the destination and future behaviours. Thus, satisfaction will result in higher revisit behaviours and higher recommendations to friends and family members, which, in turn, promotes the development of the destination (Chen \& Tsai, 2007; Lee, 2009). This form of communication is very important since recommendations help other tourists, especially first time visitors, to assess the destination (Tasci \& Kozak, 2006).

Currently, the intention to recommend a destination to other people is considered one of the most common ways of measuring loyalty (Mat Som et al., 2012). Furthermore, according to Prayag, Hosany, Muskat, \& Del Chiappa (2017), the global image positively influences the intention to recommend a destination (Bigné et al., 2001; Hosany et al., 2006; Prayag et al., 2017). Thus, it makes sense to affirm that the global destination image influences the intention to recommend. In addition, it is possible to assert that a good positioning of the global image of a destination in the visitors' mind can act as a differentiating factor among competing destinations (Chen \& Tsai, 2007). To analyse the relation between the global image of the destination and the intention to recommend, it is possible to postulate the following hypothesis:

H7: Satisfaction has a positive impact on the intention to recommend a destination.

\section{Opposition to Competing Destinations}

The act of speaking negatively about competitive brands is described by Marticotte, Arcand, \& Baudry (2016) as 'negative word-ofmouth'; consumers speak ill of a product with which they have had a bad experience or with which they haven't even had a direct experience. A strong positive relationship between a consumer and a brand can lead to negative behaviours towards other brands and is considered as competition. The purpose is to belittle a certain brand/destination that can be assumed as competitor to the destination of choice for that consumer (Marticotte et al., 2016).

According to Marticotte, Arcand, \& Baudry (2016), the act of 'trash-talking', also known as oppositional brand referrals (in our case, to opposing competing destinations), applies to the evangelistic consumers of a brand. Considering the fact that the global image of a destination corresponds to the general impressions that a brand has on the mind of the consumers (Sung \& Yang, 2008) and that the image influences the future behaviours of a visitor (Assaker et al., 2011; Bigné et al., 2001), it can be asserted that the global image of the brand destination influences the opposition to competing destinations. Tourists will feel more connected to the destination that satisfies them; thus, the following research hypothesis was proposed:

H8: Satisfaction with the destination
strengthens the opposition to competing
destinations.




\section{Research Model and Investigation Hypotheses \\ Research Model}

Based on the existing literature, a conceptual model was proposed (figure 1), accompanied by the corresponding research hypotheses. For the due effects, four antecedents of the global destination image have been considered with four possible outcomes.

\section{Methodology}

\section{Data Collection}

In the line of contemporary research works related to destination image management, this study was based on a database composed of tourists, locals and foreigners, who visited the city of Coimbra less than a year ago. The survey was distributed both face-to-face and digitally during the months of March and April 2017. The face-to-face questionnaire was applied randomly to people who were visiting the most important points of the touristic circuit in Coimbra. The online survey was distributed via Facebook pages related to tourism and travel.

In a total of 255 respondents, 135 were female and 120 male, more than half of the respondents $(52 \%)$ were 25 years old, the majority $(74.9 \%)$ of the respondents were single and less than half $(39.2 \%)$ reported to have an average monthly income between $€ 500$ and $€ 999$. In addition, more than half of the individuals, more precisely 135, had a bachelor's or higher degree ( 53\%), and more than half $(65.9 \%)$ was living in Portugal at that time.

\section{Operationalisation of the Variables}

The variables were gathered from several original scientific articles in the areas of marketing and tourism. The scales where then selected, translated and adapted. Considering the chosen variables and the very nature of the investigation, all of them constitute quantitative variables (Likert scale).

Thus, in the first group, the antecedents were operationalised by four variables: memorable experience (Şahin et al., 2011), the affective image (Agapito et al., 2010), three dimensions of the cognitive image (Martín \& Bosque, 2008), and brand personality (Rauschnabel et al., 2016). The global destination image was adapted from Kock, Josiassen, \& Assaf (2016). In the second group, the outcomes were considered to contain four variables: satisfaction (Wang, 2010), and three other factors of brand evangelism which are: intention to return (Tosun et al, 2015), intention to recommend (Prayag et al., 2017), and opposition to competing destinations (Becerra \& Badrinarayanan, 2013)

\section{Confirmatory Factor Analysis}

Through the exploratory and confirmatory factor analysis, considering the full model evaluation, using the statistical software IBM SPSS and IBM SPSS AMOS (version 21), it is possible to verify that the measurement model presents a satisfactory adjustment value (Appendix 1 and 2). After the analysis of the change indexes, where the elimination of five items occurred, the adjustment values improved slightly $(\mathrm{IFI}=0.90 ; \mathrm{TLI}=0.89 ; \mathrm{CFI}=$

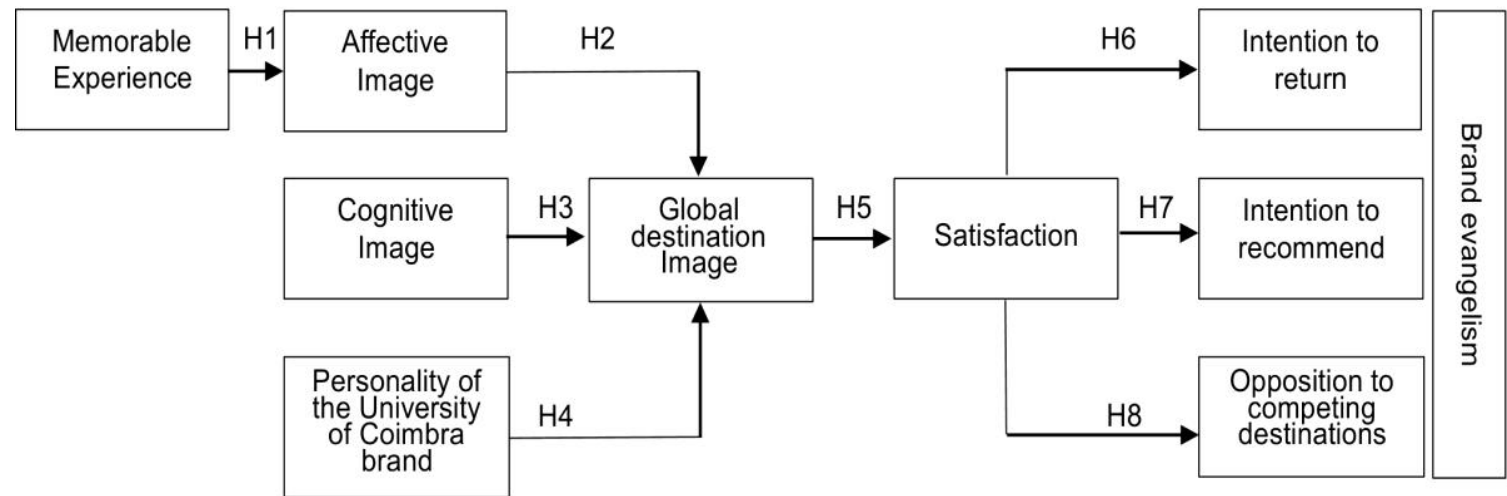

Figure 1. Conceptual model proposal 
Table 1. Final Confirmatory Factorial Analysis

\begin{tabular}{|c|c|c|c|c|c|c|c|c|c|c|c|c|c|}
\hline & $\begin{array}{c}\text { Mea } \\
\mathrm{n}\end{array}$ & SD & $\mathrm{X} 1$ & $\mathrm{X} 2$ & X3 & $\mathrm{X} 4$ & $\times 5$ & $\times 6$ & $\mathrm{X} 7$ & $\mathrm{X} 8$ & $\times 9$ & CR & AVE \\
\hline $\mathrm{X} 1$ & 5.20 & 0.77 & 0.88 & & & & & & & & & 0.84 & 0.64 \\
\hline$x 2$ & 5.41 & 1.01 & 0.47 & 0.74 & & & & & & & & 0.76 & 0.44 \\
\hline X3 & 5.15 & 1.13 & 0.78 & 0.47 & 0.96 & & & & & & & 0.95 & 0.82 \\
\hline X4 & 5.52 & 1.04 & 0.60 & 0.43 & 0.55 & 0.97 & & & & & & 0.98 & 0.88 \\
\hline$\times 5$ & 5.84 & 1.17 & 0.47 & 0.78 & 0.37 & 0.43 & 0.96 & & & & & 0.96 & 0.85 \\
\hline$\times 6$ & 5.67 & 1.24 & 0.74 & 0.41 & 0.59 & 0.51 & 0.45 & 0.89 & & & & 0.90 & 0.76 \\
\hline X7 & 5.46 & 1.20 & 0.69 & 0.44 & 0.65 & 0.50 & 0.48 & 0.82 & 0.90 & & & 0.90 & 0.76 \\
\hline X8 & 5.93 & 1.19 & 0.67 & 0.42 & 0.62 & 0.52 & 0.44 & 0.90 & 0.78 & 0.95 & & 0.95 & 0.88 \\
\hline X9 & 2.15 & 1.26 & -0.07 & 0.04 & 0.00 & 0.01 & 0.03 & -0.00 & 0.02 & 0.02 & 0.88 & 0.88 & 0.72 \\
\hline
\end{tabular}

Note: SD - Standard Deviation; Diagonal in bold - Alpha of Cronbach; CR - Composite reliability; AVE - Mean extracted variance; (X1 - Cognitive image; X2 - Affective image; X3 - Memorable experience; X4 - Personality of University of Coimbra; X5 - Global Destination Image; X6 - Satisfaction; X7 - Intention to return; X8 - Intention to recommend; $X 9$ - Opposition to competing destinations)

Table 2. Final Results for the Hypothesis

\begin{tabular}{|c|c|c|c|c|c|}
\hline \multicolumn{4}{|c|}{ Hypothesis: } & \multirow{2}{*}{$\begin{array}{c}\text { Coefficients } \\
0.463\end{array}$} & \multirow{2}{*}{$\mathbf{p}$} \\
\hline $\mathrm{H} 1$ & Memorable experience & $\rightarrow$ & Affective image & & \\
\hline $\mathrm{H} 2$ & Affective image & $\rightarrow$ & Global destination image & 0.689 & ** \\
\hline H3 & Cognitive image & $\rightarrow$ & Global destination image & 0.074 & \\
\hline $\mathrm{H} 4$ & Personality of the brand UC & $\rightarrow$ & Global destination image & 0.139 & * \\
\hline H5 & Global destination image & $\rightarrow$ & Satisfaction & 0.478 & ** \\
\hline H6 & Satisfaction & $\rightarrow$ & Intention to return & 0.834 & ** \\
\hline $\mathrm{H} 7$ & Satisfaction & $\rightarrow$ & Intention to recommend & 0.905 & ** \\
\hline $\mathrm{H} 8$ & Satisfaction & $\rightarrow$ & $\begin{array}{l}\text { Opposition to competing } \\
\text { destinations }\end{array}$ & 0.006 & \\
\hline
\end{tabular}

Note: ${ }^{*} \mathrm{p}<0.05 ; \mathrm{p}^{\star \star}<0.01$ (one-tailed t-tests)

$0.90 ; \mathrm{RMSEA}=0.06$ and $\mathrm{X} 2 / \mathrm{DF}=1.67)$.

In a detailed analysis of the measurement model (evaluation of standardised coefficients, multivariate normality, reliability of each indicator, reliability of each latent variable, and analysis of the discriminant validity), we ascertained that there are no values that deviate from the values recommended in literature. For almost all latent variables, both the composite reliability (CR) and the average variance extracted (AVE) values are above the recommended values of 0.7 and 0.5 , respectively (Table 1$)$.

\section{Results and Discussion}

To test the previously enumerated hypothesis, we analysed the structural equations using the method of maximum likelihood. The adjustment values of the structural model are once again satisfactory $(\mathrm{IFI}=0.89 ; \mathrm{TLI}=0.88 ; \mathrm{CFI}=0.89$;
RMSEA $=0.66$ and $X 2 / D F=1.94)$. We verified that the results support most of the hypotheses; however, some of the initially formulated ones were rejected.

Analysing the results in Table 2, we demonstrated that at a $5 \%$ level of significance, a large number of hypotheses confirm the positive relationship between the variables as initially formulated. It is important to highlight the fact that memorable experience has a positive impact on the affective image $(\mathrm{H} 1: \mathrm{b}=$ $0.463 ; p<0.01$ ) as previously formulated. Thus, the results of this investigation reinforce the conclusions already drawn by Prayag et al. (2017), who had shown that the tourists' emotional experiences, which are unique and memorable, act as antecedents of the perceived image. Herein, this is to emphasise once again that the better the tourist 
experience is, the better image of the destination is formed.

By analysing the results depicted in Table 2 we can also conclude that the affective image, as well as the personality of the brand 'University of Coimbra', have a positive impact on the global destination image of the 'city of Coimbra' $(\mathrm{H} 2: \mathrm{b}=0.689, \mathrm{p}<0.01 ; \mathrm{H} 4: \mathrm{b}=0.139, \mathrm{p}<$ 0.05). As previously proposed by Martín \& Bosque (2008), it makes sense that the affective image influences the global destination image, since the affective dimension represents the set of total feelings that the tourist has of a certain destination and is one of the components that constitute the global image of the destination. In addition, as shown by Hosany, Ekinci, \& Uysal (2006), it can be assumed from our study that the personality of the brand UC has a positive impact on the perceived image of the destination, influencing the future behaviour of consumers as well. It is also worth noting that the global image has a positive impact on satisfaction towards the destination $(\mathrm{H} 5: \mathrm{b}=$ $0.478, p<0.01$ ) that leads us to some conclusions already reached in previous studies (Bigné et al., 2001; Chen \& Phou, 2013; Kim et al., 2013; Lee, 2009; Pais, 2015).

Nevertheless, regarding the satisfaction with the destination, we need to emphasize that satisfaction has a direct impact on the intention to return to that destination $(\mathrm{H} 6: \mathrm{b}=0.834, \mathrm{p}<$ 0.01 ) and to recommend that destination to others $(\mathrm{H} 7: \mathrm{b}=0.905, \mathrm{p}<0.01)$. Thus, we highlight the fact that a tourist experiencing a favourable global image of a destination is a satisfied tourist and has a higher probability to return and recommend that same destination to others, as concluded by several other authors (Agapito et al., 2010; Bigné et al., 2001; Chi \& Qu, 2008; Hosany et al., 2006; Lee, 2009; Prayag et al., 2017).

From the set of formulated hypotheses, when designing the conceptual model, it was not possible to confirm the fact that cognitive image has an impact on global image $(\mathrm{H} 3: \mathrm{b}=0.074$, $p>0.05)$, which in turn has an impact on the opposition to competing destinations (H8: $b=$ $0.006, p>0.05)$. The fact that the premise put forward in $\mathrm{H} 3$ could not be corroborated in this study can be related to the notion that nowadays people see the more affective attributes of the cities as being truly important for the global image of the destinations, pushing the more cognitive questions into the background. More rational questions, as happens with commercial brands, can become less important when differentiating between options.

Finally, we emphasise that our study did not corroborate H8. Regarding this topic, we verified that even though a tourist may be satisfied with a certain tourist destination, this satisfaction does not lead to an opposition to competing destinations. The fact that a tourist likes a destination does not indicate that the person will not develop similar feelings for other destinations. We can now assert that oppositional brand referral is a concept that has probably no place in tourists' satisfaction, since product brand and global destination image are most likely seen in a different perspective (Hankinson, 2004).

\section{Final considerations}

There are several authors who have noted that the global destination image plays an important role in the marketing of tourist destinations, specifically in consumer behaviour related issues; A consumer's motivation for visiting a destination will be triggered by the expectations towards that same destination (Agapito et al., 2013; Andrades-Caldito et al., 2012; Beerli \& Martín, 2004; Bigné et al., 2001; Chi \& Qu, 2008; Chon, 1991; Mackay \& Fesenmaier, 1997; Tasci, Gartner, \& Cavusgil, 2007). It is possible to state that the global image of a certain tourist destination can influence tourists, resulting in the success or failure of its marketing strategy (Baloglu \& Mangaloglu, 2001; Beerli \& Martín, 2004). This is due to the fact that the global image influences not only consumer behaviour but also the levels of satisfaction and the attitude before, during, and after the visit (Agapito, Mendes, \& Valle, 2010; Agapito, Valle, \& Mendes, 2013; Bigné, Sánchez, \& Sánchez, 2001; Chi \& Qu, 2008; Gallarza, Saura, \& García, 2002; Jenkins, 1999). Thus, it is likely that consumer behaviour is influenced, albeit partially, by the global image of the destination. 
Based on the results of the analysis made through the structural equations model, it is possible to conclude that the memorable experience $(\mathrm{H} 1)$, the affective image $(\mathrm{H} 2)$, and the personality of the brand $\mathrm{UC}(\mathrm{H} 5)$ play an important role in the development of the global image of the destination of the brand 'city of Coimbra'. Regarding the outcomes, only H8, relating to the variable opposition to competing destinations, was not corroborated by our study. This could be due to the fact that the respondents did not intend to actively speak in a negative way about other tourist destinations in favour of Coimbra, although they feel satisfied with their visit. Therefore, it can be concluded that, contrary to some other investigations, especially for the tourist destination Coimbra, not all the chosen antecedents and outcomes were found to be statistically significant in this study.

\section{Theoretical Implications}

It is noteworthy that respondents associated adjectives such as recognised, respected, prestigious, useful, attractive, special, and international to characterise the personality of the University of Coimbra. This can help in creating a brand image and a communication strategy with which the visitors of Coimbra identify themselves with, since the University of Coimbra is the most visited touristic place in this destination. Thus, this study contributes to the advancement of knowledge by highlighting the role of memorable experience and affective image on the global destination image and by presenting for the first time the impact of the personality of the brand UC on the city's global image.

\section{Practical Implications}

Considering the practical contributions, it is important to emphasise that cities can work to improve their global image and thus be able to enjoy the advantages of having satisfied tourists. It should be noted that this investigation contributes to the characterisation of the tourist visiting Coimbra. An adequate strategy for a tourist destination has to rely on the sociodemographic data of the targets and also in the creation of a positive and focused image of the destination brand, considering the adequate segments, requiring the joint work of marketing managers and tourism managers.
Thus, tourists can make choices based on their specific wishes and needs.

\section{Limitations and future lines of research}

This study has some limitations: i) the sampling method was non-probabilistic and ii) it was difficult to gather data, resulting in a relatively small sample size. Both these factors did not allow to extrapolate or generalise the data into the population with a high confidence level. A longitudinal analysis could also provide other conclusions considering a temporal framework. Respondents may not have had the ability to give the desired answers (because the questions are closed and limited, or because they are reluctant to disclose some ideas). Since the questions can be misinterpreted without the possibility of clarification, it was not possible to know the emotions and feelings of the respondents or to ask in-depth questions regarding the variables in this study (Shukla, 2008).

Importantly, for future research, some methodological aspects can be changed: i) the use of other sampling types and ii) other information gathering methods. It is also advisable to use a larger sample size making it possible to extrapolate the results with a reasonable confidence level.

Other tourist destinations, national or international, can be used to validate the results reproduced here. In addition, it is recommended to carry out this study as a longitudinal analysis, enabling conclusions about the evolution of the global image of the brand Coimbra in the course of time.

Lastly, it is recommended to use additional variables for this conceptual model. Future research on the global destination image will allow advancement on the definition of the concept and will help understand its importance for the promotion of Coimbra and other tourist destinations as drivers of the regional and national economies. Only destinations with a well-defined brand that is positively understood by tourists will be able to answer the increasing desires and needs of tourists. Thus, the tourist destinations will become competitive in an increasingly globalised market. 


\section{References}

Aaker, J. (1997). Dimensions of brand personality. Journal of Marketing Research, 34(3), 347-356.

Agapito, D. (2010). A Imagem de Lagos Enquanto Destino Turístico: Perspetiva dos Turistas Versus Perspetiva dos Residentes. Master

Dissertation.Universidade do Algarve.

Agapito, D., Mendes, J., \& Valle, P. (2010). Destination Image: Perspectives of Tourists versus Residents. European Journal of Tourism, Hospitality and Recreation, I(1), 90-109.

Agapito, D., Valle, P. O., \& Mendes, J. C. (2013). The Cognitive-Affective-Conative Model of Destination Image: A Confirmatory Analysis. Journal of Travel \& Tourism Marketing, 30(5), 471-481.

Andrades-Caldito, L., Sanchez-Rivero, M., \& Pulido-Fernandez, J. I. (2012). Differentiating Competitiveness through Tourism Image Assessment: An Application to Andalusia (Spain). Journal of Travel Research, 52(1), 68-81.

Araújo, L. (2015). Alta de Coimbra: Evolução urbana e funcionalidades. Universidade de Coimbra.

Assaker, G., Vinzi, V. E., \& O'Connor, P. (2011). Examining the effect of novelty seeking, satisfaction, and destination image on tourists' return pattern: A two factor, non-linear latent growth model. Tourism Management, 32(4), 890-901.

Baloglu, S., \& Brinberg, D. (1997). Affective images of tourism destinations. Journal of Travel Research, 35 (4), 11-15.

Baloglu, S., \& Mangaloglu, M. (2001). Tourism destination images of Turkey, Egypt, Greece, and Italy as perceived by USbased tour operators and travel agents. Tourism Management, 22(1), 1-9.

Baloglu, S., \& Mccleary, K. W. (1999). A model of destination image formation. Annals of Tourism Research, 26(4), 868-897.

Becerra, E. P., \& Badrinarayanan, V. (2013). The influence of brand trust and brand identification on brand evangelism. Journal of Product \& Brand Management, 22(5), 371-383.

Beerli, A., \& Martín, J. D. (2004). Factors influencing destination image. Annals of Tourism Research, 31(3), 657-681.
Bigné, J. E., Sánchez, M. I., \& Sánchez, J. (2001). Tourism image, evaluation variables and after purhase behaviour: Inter-relationship. Tourism Management, 22(6), 607-616.

Bosque, I. A. R. del, \& Martín, H. S. (2008). Tourist satisfaction a cognitive-affective model. Annals of Tourism Research, 35(2), 551-573.

Brea, J. A., \& Cardoso, L. (2011). Tourism destination image: Reflexão sobre as principais investigações internacionais. CULTUR: Revista de Cultura e Turismo, 5(2), 4-18.

Buhalis, D. (2000). Marketing the Competitive Destination of the Future. Tourism Management, 21(1), 97-116.

Chan, C. S., \& Marafa, L. M. (2016). Perceptual content analysis for city image: a case study of Hong Kong. Asia Pacific Journal of Tourism Research, 21(12), 1285-1299.

Chen, C. F., \& Phou, S. (2013). A closer look at destination: Image, personality, relationship and loyalty. Tourism Management, 36, 269-278.

Chen, C. F., \& Tsai, D. (2007). How destination image and evaluative factors affect behavioral intentions? Tourism Management, 28(4), 1115-1122.

Chi, C. G. Q., \& Qu, H. (2008). Examining the structural relationships of destination image, tourist satisfaction and destination loyalty: An integrated approach. Tourism Management, 29(4), 624-636.

Chon, K. S. (1991). Tourism destination image modification process. Tourism Management, 12(1), 68-72.

Domingues, C., \& Carvalho, P. (2013). Acessibilidade e turismo na cidade de Coimbra. TurYDes - Revista de Investigación En Turismo Y Desarrollo Local, 6(14), 1-23.

Echtner, C. M., \& Ritchie, J. B. (1993). The measurement of destination image: an empirical assessment. Journal of Travel Research, 31(4), 3-13.

Echtner, C. M., \& Ritchie, J. R. B. (2003). The meaning and measurement of destination image. Journal of Tourism Studies, 14(1), 37-48.

Freire, J. R. (2011). Branding Lisbon - Defining the scope of the city brand. Hampshire: Palgrave Macmillan. 
Gallarza, M., Saura, I., \& García, H. (2002). Destination Image: Towards a conceptual framework. Annals of Tourism Research, 29(1), 56-78.

Gartner, W. C. (1994). Image Formation Process. Journal of Travel \& Tourism Marketing, 2 (2-3), 191-216.

Hankinson, G. (2004). Relational network brands: Towards a conceptual model of place brands. Journal of Vacation Marketing, 10(2), 109-121.

Hernández-Mogollón, J. M., Duarte, P. A., \& Folgado-Fernández, J. A. (2016). The contribution of cultural events to the formation of the cognitive and affective images of a tourist destination. Journal of Destination Marketing and Management, 8 (March), 170-178.

Hosany, S., Ekinci, Y., \& Uysal, M. (2006). Destination image and destination personality: An application of branding theories to tourism places. Journal of Business Research, 59(5), 638-642.

Hudson, S., \& Ritchie, J. R. B. (2009). Branding a memorable destination experience. The case of "Brand Canada." International Journal of Tourism Research, 11(2), 217228.

Jenkins, O. (1999). Understanding and measuring tourist destination. International Journal of Tourism Research, 1(1), 1-15.

Kim, Holland, S., \& Han, H. (2013). A Structural Model for Examining how Destination Image, Perceived Value, and Service Quality Affect Destination Loyalty: a Case Study of Orlando. Internation Journal of Tourism Research, 15, 313-328.

Kim, \& Perdue, R. (2011). The Influence of Image on Destination Attractiveness. Journal of Travel \& Tourism Marketing, 28(3), 225-239.

Kock, F., Josiassen, A., \& Assaf, A. G. (2016). Advancing destination image: The destination content model. Annals of Tourism Research, 61, 28-44.

Lee, T. H. (2009). A Structural Model to Examine How Destination Image, Attitude, and Motivation Affect the Future Behavior of Tourists. Leisure Sciences, 31(3), 215236.

Lee, Lee, C.-K., \& Lee, J. (2014). Dynamic nature of destination image and influence of tourist overall satisfaction on image modification. Journal of Travel Research, 53(2), 239-251.

Li, X. R., \& Kaplanidou, K. K. (2013). The Impact of the 2008 Beijing Olympic Games on China's Destination Brand: A U.S.-Based Examination. Journal of Hospitality and Tourism Research, 37(2), 237-261.

Mackay, K. J., \& Fesenmaier, D. R. (1997). Pictorial Element of Destination in Image Formation. Annals of Tourism Research, 21(3), 537-565.

Marticotte, F., Arcand, M., \& Baudry, D. (2016). The impact of brand evangelism on oppositional referrals towards a rival brand. Journal of Product \& Brand Management, 25(6), 538-549.

Martín, H. S., \& Bosque, I. (2008). Exploring the cognitive-affective nature of destination image and the role of psychological factors in its formation. Tourism Management, 29(2), 263-277.

Mat Som, A. P., Marzuki, A., Yousefi, M., \& AbuKhalifeh, A. N. (2012). Factors influencing visitors' revisit behavioral intentions: A case study of Sabah, Malaysia. International Journal of Marketing Studies, 4(4), 39-50.

Matos, N., Mendes, J., \& Valle, P. (2012). Revisiting the Destination Image Construct Through a Conceptual Model. Dos Algarves: A Multidisciplinary EJournal, 21, 101-117.

Oppermann, M. (2000). Tourism Destination Loyalty. Journal of Travel Research, 39, 78-84.

Pais, A. (2015). Implicações Da Imagem Dos Destinos No Comportamento Dos Visitantes: O Caso De Ponte de Lima. Universidade de Aveiro.

Pan, L., Zhang, M., Gursoy, D., \& Lu, L. (2017). Development and validation of a destination personality scale for mainland Chinese travelers. Tourism Management, 59, 338-348.

Patel, N. (2015). What Does A Brand Evangelist Do, And Do You Need One? Retrieved November 3, 2016, from http://www.forbes.com/sites/neilpatel/2015 /12/31/what-does-a-brand-evangelist-doand-do-you-need-one/\#23dbf1a33f42

Pike, S., \& Ryan, C. (2004). Destination Positioning Analysis through a 
Comparison of Cognitive, Affective and Conative Perceptions. Journal of Travel Research, 42(4), 333-342.

Poria, Y., Reichel, A., Cohen, R. (2013). Tourist Perceptions of World Heritage Sites and Its Designation. Tourism Management, 35 (2), 72-74.

Prayag, G., Hosany, S., Muskat, B., \& Del Chiappa, G. (2017). Understanding the Relationships between Tourists Emotional Experiences, Perceived Overall Image, Satisfaction, and Intention to Recommend. Journal of Travel Research, 56(1), 41-54.

Qu, H., Hyunjung, L., \& Hyunjung, H. (2011). A model of destination branding: Integrating the concepts of the branding and destination image. Tourism Management, 32(3), 465-476.

Rauschnabel, P. A., Krey, N., Babin, B. J., \& Ivens, B. S. (2016). Brand management in higher education: The University Brand Personality Scale. Journal of Business Research, 69(8), 3077-3086.

Rutter, R., Lettice, F., \& Nadeau, J. (2016). Brand personality in higher education: anthropomorphized university marketing communications. Journal of Marketing for Higher Education, 27 (1), 1-21.

Şahin, A., Zehir, C., \& Kitapçi, H. (2011). The effects of brand experiences, trust and satisfaction on building brand loyalty; an empirical research on global brands. Procedia - Social and Behavioral Sciences, (24), 1288-1301.

San Martín, H., \& Rodríguez del Bosque, I. A. (2008). Exploring the cognitive-affective nature of destination image and the role of psychological factors in its formation. Tourism Management, 29(2), 263-277.

Santos, N. (2012). Sustentabilidade Urbana. Território e aplicabilidade. A cidade e os novos desafios urbanos. In Rui Jacinto, Iberografias, 20, CEI, Guarda, 205-234.
Shukla, P. (2008). Essentials of Marketing Research. Paurav Shukla \& Ventus Publishing ApS.

Stern, E., \& Krakover, S. (1993). The Formation of a Composite Urban Image. Geographical Analysis, 25(2), 130-146.

Sung, M., \& Yang, S.-U. (2008). Toward the model of university image: The influence of brand personality, external prestige, and reputation. Journal of Public Relations Research, 20(4), 357-376.

Tasci, A., \& Gartner, W. (2007). Destination Image and Its Functional Relationships. Journal of Travel Research, 45(4), 413425.

Tasci, A., Gartner, W., \& Cavusgil, S. T. (2007). Conceptualization and operationalization of destination image. Journal of Hospitality \& Tourism Research, 31(2), 194-223.

Tasci, A., \& Kozak, M. (2006). Destination brands vs destination images: Do we know what we mean? Journal of Vacation Marketing, 12(4), 299-317.

Tosun C., Dedeoglu B.B \& Fyall A. (2015). Destination service quality, affective image and revisit intention: the moderating role of past experience. Journal of Destination Marketing \& Management, 4 (4), 222-234.

Tung, V., \& Ritchie, J. (2011). Exploring the essence of memorable tourism experiences. Annals of Tourism Research, 38(4), 1367-1386.

Wang, J. (2008). The power and limits of branding in national image communication in global society. The Journal of International Communication, 14(May), 9-24.

Zhang, H., Fu, X., Cai, L. A., \& Lu, L. (2014). Destination image and tourist loyalty: A meta-analysis. Tourism Management, 40, 213-223. 


\section{Appendix 1. Exploratory factor analysis (EFA)}

\begin{tabular}{lcccc}
\hline & $\begin{array}{c}\text { Cronbach } \\
\text { Alpha }\end{array}$ & kmo & $\begin{array}{c}\text { Bartlett } \\
\text { test }\end{array}$ & $\begin{array}{c}\text { \% Of Variance } \\
\text { Explained }\end{array}$ \\
\hline X1 - Cognitive image & 0.926 & 0.898 & 0.000 & 46.38 \\
X2 - Affective image & 0.740 & 0.710 & 0.000 & 56.92 \\
X3 - Memorable experience & 0.957 & 0.938 & 0.000 & 63.36 \\
X4 - Personality of University of Coimbra & 0.974 & 0.957 & 0.000 & 63.12 \\
X5 - Global Destination Image & 0.958 & 0.872 & 0.000 & 88.92 \\
X6 - Satisfaction & 0.893 & 0.713 & 0.000 & 89.03 \\
X7 - Intention to return & 0.865 & 0.775 & 0.000 & 72.69 \\
X8 - Intention to recommend & 0.954 & 0.773 & 0.000 & 91.70 \\
X9 - Opposition to competing destinations & 0.877 & 0.715 & 0.000 & 80.70 \\
\hline
\end{tabular}


Bairrada, C., M. Vieira and J. Fontes da Costa (2019) / European Journal of Tourism Research 21, pp. 87-101

\section{Appendix 2 Confirmatory factor analysis (CFA)}

\begin{tabular}{|c|c|c|c|}
\hline \multicolumn{2}{|c|}{ 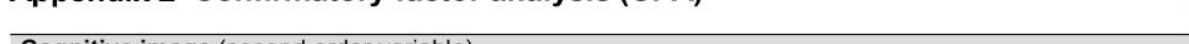 } & \multirow[t]{2}{*}{ SRW } & \multirow[t]{2}{*}{ CR } \\
\hline Cognitive image (second-order var & & & \\
\hline \multirow{3}{*}{$\begin{array}{c}\text { Natural } \\
\text { environment }\end{array}$} & Coimbra is characterized by the variety of fauna and flora. & 0.57 & - \\
\hline & Coimbra has beautiful landscapes. & 0.80 & 8.87 \\
\hline & Coimbra has beautiful natural parks. & 0.84 & 9.00 \\
\hline \multirow{3}{*}{$\begin{array}{c}\text { Cultural } \\
\text { environment }\end{array}$} & There are a lot of cultural attractions in Coimbra. & 0.84 & 11.80 \\
\hline & The city of Coimbra owns a lot of cultural attractions. & 0.86 & 11.97 \\
\hline & In Coimbra it's easy to learn about the local manners. & 0.70 & - \\
\hline \multirow{4}{*}{$\begin{array}{l}\text { Infrastructures/Socioeconomic } \\
\text { environment }\end{array}$} & Coimbra has good shopping facilities. & 0.70 & 11.46 \\
\hline & Coimbra is a city with good quality accommodation. & 0.79 & 13.18 \\
\hline & Coimbra is a destination with good value for the money. & 0.82 & - \\
\hline & The city of Coimbra is safe. & 0.70 & 11.45 \\
\hline \multicolumn{4}{|l|}{ Affective image } \\
\hline \multirow{4}{*}{\multicolumn{2}{|c|}{$\begin{array}{l}\text { The city of Coimbra is arousing. } \\
\text { The city of Coimbra is pleasant. } \\
\text { The city of Coimbra is exciting. } \\
\text { The city of Coimbra is relaxing. }\end{array}$}} & 0.76 & 13.14 \\
\hline & & 0.73 & 12.37 \\
\hline & & 0.66 & 11.01 \\
\hline & & 0.48 & 7.47 \\
\hline Memorable experience (second-or & variable) & & \\
\hline & The city of Coimbra creates a strong impression in my five senses. & 0.90 & - \\
\hline Sensory & I find the city of Coimbra interesting in a sensory way. & 0.89 & 21.30 \\
\hline & Coimbra as a destination appeals to my senses. & 0.89 & 21.03 \\
\hline & The city of Coimbra creates feelings and emotions. & 0.93 & - \\
\hline Affective & I do have strong emotions/feelings for the city of Coimbra. & 0.93 & 25.20 \\
\hline & I consider the city of Coimbra an emotional brand. & 0.85 & 20.24 \\
\hline & $\begin{array}{l}\text { I engage in physical actions and behaviors when I visit the city of } \\
\text { Coimbra. }\end{array}$ & 0.83 & - \\
\hline Intellectual & The city of Coimbra brand results in bodily experiences. & 0.88 & 17.00 \\
\hline & The city of Coimbra is action oriented. & 0.82 & 15.21 \\
\hline & I engage in a lot of thinking when I visit the city of Coimbra. & 0.87 & - \\
\hline Behavioral & $\begin{array}{l}\text { The city of Coimbra stimulates my curiosity and problem solving } \\
\text { skills. }\end{array}$ & 0.83 & 16.82 \\
\hline & The city of Coimbra makes me think. & 0.89 & 19.21 \\
\hline Personality of University of Coim & (second-order variable) & & \\
\hline The University of Coimbra is: & & & \\
\hline & Accepting & - & - \\
\hline & Leading & 0.82 & - \\
\hline Prestige & Reputable & 0.82 & 15.51 \\
\hline & Successful & 0.91 & 18.13 \\
\hline & Considerate & 0.86 & 16.67 \\
\hline & Humane & 0.81 & - \\
\hline & Helpful & 0.88 & 16.67 \\
\hline Sincerity & Friendly & 0.86 & 16.22 \\
\hline & Trustworthy & 0.88 & 16.75 \\
\hline & Fair & - & - \\
\hline & Attractive & 0.83 & - \\
\hline Appeal & Productive & 0.85 & 16.79 \\
\hline & Special & - & - \\
\hline & Athletic & 0.71 & - \\
\hline livelv & Dynamic & 0.87 & 13.14 \\
\hline LIVely & Lively & 0.82 & 12.40 \\
\hline & Creative & 0.87 & 13.09 \\
\hline & Organized & 0.86 & - \\
\hline & Competent & 0.93 & 21.66 \\
\hline Conscientiousness & Structured & 0.93 & 21.68 \\
\hline & Effective & 0.91 & 20.57 \\
\hline & Networked & 0.82 & - \\
\hline Cosmopolitan & International & - & - \\
\hline & Cosmopolitan & 0.73 & 12.98 \\
\hline Global destination Image & & & \\
\hline Globally. I consider Coimbra as a ge & tourism destination. & 0.95 & 20.27 \\
\hline Globally. I consider Coimbra as a p & tive tourism destination. & 0.92 & 19.10 \\
\hline Globally. I consider Coimbra as a fa & rable tourism destination. & 0.93 & 19.66 \\
\hline Globally. I consider Coimbra as a w & hwhile tourism destination. & 0.89 & 18.17 \\
\hline Satisfaction & & & \\
\hline I really enjoyed this trip. & & 0.93 & 19.23 \\
\hline My choice to visit Coimbra was a wi & one. & 0.93 & 19.31 \\
\hline This tourist experience in Coimbra & exactly what I expected. & 0.74 & 13.68 \\
\hline Intention to return & & & \\
\hline I would like to revisit Coimbra in the & ar future. & 0.83 & 15.78 \\
\hline If I had to decide again I would choo & Coimbra again. & 0.92 & 18.85 \\
\hline I would like to visit the city of Coimb & nore frequently. & 0.86 & 16.75 \\
\hline Considered with other destinations. & imbra would be my first choice. & - & - \\
\hline Intention to recommend & & & \\
\hline I will recommend Coimbra to other $\mathrm{p}$ & ple. & 0.91 & 18.79 \\
\hline I will say positive things about Coim & to other people. & 0.94 & 20.04 \\
\hline I will encourage friends and relative & visit Coimbra. & 0.95 & 20.34 \\
\hline Opposition to competing destinat & & & \\
\hline I spread negative word-of-mouth ab & other destinations. & 0.77 & 13.99 \\
\hline I denigrate other tourism destination & my friends. & 0.95 & 18.58 \\
\hline When my friends ask me for advice. & ell them not to visit destinations otr & 0.81 & 14.92 \\
\hline
\end{tabular}

Note: SRW - Standardized Regression Weights; CR - Critical Ratio 